\title{
Appendix 4: Publication Resources
}

\begin{tabular}{|c|c|c|c|c|c|}
\hline Journa & $F$ & Joumal & $F$ & bournal & $\mathbf{F}$ \\
\hline British Journal of Educational Technology & 38 & Computer Assisted Language Leaming & 2 & Asia Pacific Journal Of Teacher Education & 1 \\
\hline Techtrends & 38 & Distance Education & 2 & Assessment And Evaluation in Higher Education & 1 \\
\hline Educational Technology Research And & & & & & \\
\hline Develapment & 36 & Education And Com puting & 2. & Astra Salvensis & 1 \\
\hline Educational Technology And Sociefy & 24 & Educational Policy & 2 & EMC Health Services Research & 1 \\
\hline Turkish Online Joumal of Educational Technology & 16 & Educational Psycholo gy Review & 2 & Botechnology An Indian Journal & 1 \\
\hline Computers And Education & 24 & Educational Research Review & 2 & British Journal of Educational 5tudies & 1 \\
\hline Educational Media International & 23 & $\begin{array}{l}\text { Energy Education Sdence And Technology Part A } \\
\text { Energy Science And Research }\end{array}$ & 2 & Eritish Journal of Visual Impairment & 1 \\
\hline Australasian Joumal of Educational Technology & 10 & $\begin{array}{l}\text { Energy Education Sdence And Technology Part B } \\
\text { social And Educasonal Studies }\end{array}$ & 2 & $\begin{array}{l}\text { Canadian Journal of Science Mathematics And } \\
\text { Technology Education }\end{array}$ & 1 \\
\hline Education And Information Technologies & 20 & European Journal of Contemporary Education & 2 & Child hood Education & 1 \\
\hline Jouma of Educational Computing Research & 10 & Interactive Learning Environments & 2 & Chinese Education And Society & 1 \\
\hline $\begin{array}{l}\text { Intemational Joumal of Information And } \\
\text { Communication Technology Education }\end{array}$ & & $\begin{array}{l}\text { International Journal of OVil Engineering And } \\
\text { Technology }\end{array}$ & 2 & $\begin{array}{l}\text { Clinical Laboratory Science Joumal of The } \\
\text { American Society For Medical Technology }\end{array}$ & 1 \\
\hline Jouma of Science Education And Technology & 8. & $\begin{array}{l}\text { International Journal Of Continuing Engineering } \\
\text { Education And Life Long Leaming }\end{array}$ & 2 & Clinical Psychology Science And Practice & 1 \\
\hline Leaming Media And Technology & 8 & International Journal of Educational Research & 2 & College And Research Ubraries New5 & 1 \\
\hline $\begin{array}{l}\text { Eurasia Joumal Of Mathem atics Science And } \\
\text { Technology Education }\end{array}$ & & $\begin{array}{l}\text { International Journal of Emerging Technologles } \\
\text { In Learning }\end{array}$ & 2] & College And Undergraduate Libraries & 1 \\
\hline ELeaming And Digital Media & & $\begin{array}{l}\text { International Review Of Research in Open And } \\
\text { Distance Learning }\end{array}$ & 2 & $\begin{array}{l}\text { Communications of The Association For } \\
\text { Information Systems }\end{array}$ & 1 \\
\hline Joumal of Physical Education And Sport & 6 & Iournal For Research In Mathematic Educabon & 2 & Community And Junior College Libraries & 1 \\
\hline Jouma of Research On Technology in Education & 6 & Journal of Alied Health & 2 & Convergence & 1 \\
\hline Tunkish Online Joumal of Distance Education & & $\begin{array}{l}\text { Journal of Computational And Theoretical } \\
\text { Nanoscience }\end{array}$ & 2] & Counselor Education And Supervision & 1 \\
\hline Academic Medicine & 5 & Journal of Computer Information Systems & 2 & Development Southern Africa & 1 \\
\hline Computers in The Sohools & & $\begin{array}{l}\text { Journal of information Technology Education } \\
\text { Research }\end{array}$ & 2 & Digital Scholarship in The Humanities & 1 \\
\hline Jouma Of Computer Assisted Learning & & $\begin{array}{l}\text { Journal of Information Technology for Teacher } \\
\text { Education }\end{array}$ & 2 & Disability And Rehabilitation & 1 \\
\hline Joumal of Research On Computing in Educasion & & $\begin{array}{l}\text { Journal Of Organisational Transformation And } \\
\text { 5ocial Change }\end{array}$ & 2 & Discourse & 1 \\
\hline Revista Da Escola De Enfermagem & 5 & Journal of Teaching in Travel And Tourism & 2 & Discourse Studies & 1 \\
\hline Agro Food industry Hil Tech & 4 & Kybemetes & 2 & Economist Un ited Kingdom & 1 \\
\hline Computers in Human Behavior & 4 & Library Hi Tech & 2 & Education And Self Development & 1 \\
\hline $\begin{array}{l}\text { innovations in Education And Teaching } \\
\text { Intemational }\end{array}$ & 4. & Man In india & 2) & Education And Urban Sodety & 1 \\
\hline $\begin{array}{l}\text { intem ational Joumal of Educasional Technology } \\
\text { in Higher Education }\end{array}$ & 4 & Mathematics Education & 2 & Education As Change & 1 \\
\hline AI And Society & 3 & Medical Teacher & 2 & Education Research international & 1 \\
\hline American Joumal Of Pharmaceutical Education & 3 & Mediterranean loumal Of Social Sciences & 2 & Education Sciences & 1 \\
\hline Bulletin Of Science Technology And Society & 3 & Multicultural Education And Technology Joumal & 2 & Educational Administration Quarterly & 1 \\
\hline Campus Wide information Systems & 3 & Nurse Educator & 2 & Educational Gerontology & 1 \\
\hline Communications of The ACM & 3 & $\begin{array}{l}\text { Nursing Health Care Official Publication of The } \\
\text { National League For Nursing }\end{array}$ & 2 & Educational Leadership & 1 \\
\hline EEEE Transactions On Leaming Technologies & 3 & Nursing Staff Development insider & 2 & Educational Theory & 1 \\
\hline $\begin{array}{l}\text { Intem ational Joumal of Artificial intelligence in } \\
\text { Education }\end{array}$ & 3 & Online Brazilian Journal of Nursing & 2 & Egitim Ve Bilim & 1 \\
\hline $\begin{array}{l}\text { Intern ational Joumal Of Environmental And } \\
\text { Science Education }\end{array}$ & 3 & $\begin{array}{l}\text { Dolicy Insights From The Behavioral And Brain } \\
\text { Sciences }\end{array}$ & 2 & Electronic Joumal of E Learning & 1 \\
\hline $\begin{array}{l}\text { intem ational Joumal of innovative Technology } \\
\text { And Exploring Engineering }\end{array}$ & 3 & Review of Educational Research & 2 & Electronic Magazine of Multicultural Education & 1 \\
\hline Intem ational Joumal of Learning & 3 & Revista Latino Americana De Enfermagem & 2) & Equity And Excellence in Educztion & 1 \\
\hline Intern ational Joumal of Phytoremediation & 3 & Russian Education And Society & 2 & Espacios & 1 \\
\hline Joumal Of Accounting Education & 3 & Scientometrics & 2 & Essays in Education & 1 \\
\hline Joumal of Advanced Oxidation Technologles & 3 & Studies In Philosophy And Education & 2 & Ethics And information Technology & 1 \\
\hline Jou mal Of Computing In Higher Education & 3 & Teaching And Teacher Education & 2 & European Joumal Of Engineering Education & 1 \\
\hline Jouma of Digital Learning in Teacher Education & 3 & Teoriya I Praktika Fizicheskoy Kultury & 2 & Eumpean Joum a Of Social Sciences & 1 \\
\hline Research in Learning Technology & & $\begin{array}{l}\text { Wodd Transactions On Engineering And } \\
\text { Technology Education }\end{array}$ & & $\begin{array}{l}\text { Future Of Children Center For The Future of } \\
\text { Child ren The David And Lucle Padkard } \\
\text { Foundation }\end{array}$ & 1 \\
\hline Teachers College Record & 3 & Academe & 1) & Gender And Education & 1 \\
\hline Technology Knowledge And Learning & 3 & Academic Journal Of interdisciplinary Studies & 1 & Geojournal & 1 \\
\hline Technology Pedagogy And Education & 3 & Acta Astronautica & 1) & Global Media Joumal & 1 \\
\hline Texto E Contexto Enfermagem & 3 & Acta Paulista De Enfermagem & 1 & Hawaii Medical Jouma & 1 \\
\hline Ubiquitous Learning & 3 & Action Research & 1 & Healthmed & 1 \\
\hline Advanced Science Letters & 2 & Advances in Developing Human Resources & 1 & History of Education & 1 \\
\hline Africa Education Review & 2 & Advances in Environmental Biology & 1 & Horttechnology & 1 \\
\hline Alberta Journal of Educational Research & 2 & Advancos In Natural And Applied Sciences & 1) & & \\
\hline Alt I Research in Learning Technology & 2 & American Journal of Applied Sciences & 1) & & \\
\hline Asia Pacific Education Review & 2 & American Journal of Evaluation & 1. & & \\
\hline Australian Educational Computing & 2 & Asia Pacific Education Researcher & 1 & & \\
\hline Boletin Tecrico Technical Bulletin & 2 & Asia Pacific Journal of Education & 1] & & \\
\hline
\end{tabular}

